\title{
Biotechnological approaches to enhance salidroside, rosin and its derivatives production in selected Rhodiola spp. in vitro cultures
}

\author{
Marta Grech-Baran • Katarzyna Sykłowska-Baranek • \\ Agnieszka Pietrosiuk
}

Received: 10 April 2013/Accepted: 7 June 2014/Published online: 21 June 2014

(C) The Author(s) 2014. This article is published with open access at Springerlink.com

\begin{abstract}
Rhodiola (Crassulaceae) an arctic-alpine plant, is extensively used in traditional folk medicine in Asian and European countries. A number of investigations have demonstrated that Rhodiola preparations exhibit adaptogenic, neuroprotective, antitumour, cardioprotective, and anti-depressant effects. The main compounds responsible for these activities are believed to be salidroside, rosin and its derivatives which became the target of biotechnological investigations. This review summarizes the results of the diverse biotechnological approaches undertaken to enhance the production of salidroside, rosin and its derivatives in callus, cell suspension and organ in vitro cultures of selected Rhodiola species.
\end{abstract}

Keywords Biotransformation - In vitro cultures . Rhodiola spp. Rosin derivatives $\cdot$ Salidroside

$\begin{array}{ll}\text { Abbreviations } \\ \text { BA } & \text { 6-Benzylaminopurine } \\ \text { CA } & \text { Cinnamyl alcohol } \\ \text { CAD } & \text { Cinnamyl alcohol dehydrogenase } \\ \text { CCA } & \text { Compact callus aggregates }\end{array}$

M. Grech-Baran $(\bowtie) \cdot$ K. Sykłowska-Baranek ·

A. Pietrosiuk

Department of Pharmaceutical Biology and Medicinal

Plant Biotechnology, Faculty of Pharmacy, Medical

University of Warsaw, Banacha 1 St., 02-097 Warsaw,

Poland

e-mail: mgrech@wum.edu.pl

$\begin{array}{ll}\text { CCR } & \text { Cinnamoyl-CoA reductase } \\ \text { CNS } & \text { Central Nervous System } \\ \text { DW } & \text { Dry weight } \\ \text { IAA } & \text { Indole-3-acetic acid } \\ \text { IBA } & \text { Indole-3-butyric acid } \\ \text { KT } & \text { Kinetin } \\ \text { MS } & \text { Murashige and Skoog (1962) medium } \\ \text { NAA } & \text { Naphthaleneacetic acid } \\ \text { PAL } & \text { Phenylalanine ammonia-lyase } \\ \text { Phe } & \text { L-Phenylalanine } \\ \text { SA } & \text { Salicylic acid } \\ \text { TDZ } & \text { Thidiazuron } \\ \text { Trp } & \text { L-Tryptophan } \\ \text { TGase } & \text { Tyrosol-glucosyltransferase } \\ \text { 2,4-D } & \text { 2,4-Dichlorophenoxyacetic acid } \\ \text { 4CL } & \text { Hydroxycinnamic acid CoA-ligase } \\ \text { 4-HPAA } & \text { 4-Hydroxyphenylacetaldehyde } \\ \text { Tyr } & \text { L-Tyrosine } \\ \text { TyrDC } & \text { Tyrosine decarboxylase } \\ \text { UDP } & \text { UDP-glucose:tyrosol glucosyltransferase } \\ \text { UGT } & \text { Uridine diphosphate dependent } \\ & \text { glucosyltransferase } \\ & \end{array}$

\section{Introduction}

Rhodiola spp., herbaceous perennial plants of the Crassulaceae family, are extensively used in traditional medicine in Asian and European countries 
(Tolonen et al. 2003; Yousef et al. 2006; Galambosi et al. 2010; Panossian et al. 2010). The Rhodiola species grows in regions of cool temperature, in the sub-arctic areas of the northern hemisphere, including North and Central Europe, Asia and North America (GBIF 2010 http://www.gbif.org; Galambosi 2006; Guest and Allen 2014). The genus Rhodiola is believed to originate from the mountainous regions of Southwest China and the Himalayas and nowadays is distributed in mountainous as well as coastal habitats (Brown et al. 2002).

The current taxonomic status of the genus Rhodiola is quite complex due to the generally similar morphology (Brown et al. 2002; Liu et al. 2013). According to GBIF (2010) the genus Rhodiola comprises of 136 accepted species while the Plant List (http://www.theplantlist.org) includes 135 scientific plant names of species rank for the genus Rhodiola. Of these 61 are accepted species names, 16 have not been clarified.

The morphologicals of Rhodiola plants are as follows: stems dimorphic with usually very stout caudex or rhizome, usually with brown or blackish, membranous, scalelike leaves, sharply differentiated from much more slender, erect or ascending, leafy flowering stems (Liu et al. 2013). The plant is dioecious with male and female flowers located on different plants, and rarely hermaphroditic (Tutin 1964). Among the distinguishing characters of the genus are two series of stamens totaling twice the number of petals; free or nearly free petals (not joined in a tube); a stout rhizome from whose axils the flowering stems rise (Flora of China 2001).

Recently, genotyping and chemotaxonomic markers have been used to identify Rhodiola species within the genus. On the basis of the chemical profiles of the 47 collected Rhodiola samples of $R$. crenulata, $R$. sachalinensis, $R$. himalensis, $R$. serrata, $R$. rosea, $R$. kirilowii and $R$. fastigiata it was demonstrated that different kinds of characteristics reference markers occurred at various concentrations in the different Rhodiola species. The eight compounds: rosarin, rosavin, and rosin, tyrosol and salidroside, catechin, rhodionin and gallic acid have been proposed as reference chemotaxonomic markers. Salidroside and gallic acid were found in all species while rosarin and rosin were detected in $R$. sachalinnsis, $R$. himalensis, $R$. rosea. Rosavin was characteristic only for $R$. himalensis, $R$. serrata, $R$. rosea (Liu et al. 2013).
The roots and rhizomes of Rhodiola spp. have been reported to contain distinct groups of chemical compounds (Table 1). Initially, in the 1970s, the compound responsible for its unique pharmacological properties was believed to be salidroside (Saratikov and Krasnov 1987). According to the Russian Pharmacopeia (1989), the raw material of $R$. rosea should contain $0.8 \%$ salidroside (Furmanowa et al. 1999). However, further studies revealed that not only salidroside but also rosin derivatives are important bioactive compounds (Sokolov et al. 1985, 1990; Wagner et al. 1994; Zapesochnaya et al. 1995). Wiedenfeld et al. (2007a) summarized the results of comparative studies on the activities of salidroside and rosin derivatives by Sokolov et al. $(1985,1990)$ which showed CNS, adaptogenic and immunostimulating properties, however he concluded that total Rhodiola rosea extracts are superior to the single components which indicates that the glycosides mentioned are not the only compounds responsible for the medicinal effect. In the subsequent studies it was reported that aqueous and hydroalcoholic extracts of $R$. rosea exhibited stronger neovascular reaction than rosavin applied alone (Skopińska-Różewska et al. 2008b).

Rhodiola rosea extracts used in most pharmacological studies were standardized to a minimum $3 \%$ of rosin and its derivatives and $0.8-1 \%$ salidroside because the naturally occurring ratio of these compounds in $R$. rosea root is approximately 3:1 (Brown et al. 2002).

In numerous in vitro and in vivo studies on cells and animals, the extracts or pure salidroside have been examined and have shown strong biological activity. The main effects described to date are the following: adaptogenic and stress protective (Darbinyan et al. 2000; Spasov et al. 2000; De Bock et al. 2004; Olsson et al. 2009), antioxidant (Chen et al. 2009b; Schriner et al. 2009; Calcabrini et al. 2010; Mao et al. 2010), anti-tumour (Skopińska-Różewska et al. 2008a, 2008c, Hu et al. 2010a, b; Sun et al. 2012), antidepressive (Chen et al. 2009a, Diermen et al. 2009), neuroprotective (Zhang et al. 2007b, Yu et al. 2008, Chen et al. 2009a, Yu et al. 2010), cardioprotective (Wu et al. 2009, Cheng et al. 2012) hepatoprotective (Nan et al. 2003), and immunostimulating (Seo et al. 2001, Wójcik et al. 2009, Siwicki et al. 2012). Also the cinnamyl alcohol derivate rosavin shows a stimulating effect on the CNS (Wagner et al. 1994), demonstrated as spontaneous motor action and antihypnotic 
Table 1 Chemical composition of Rhodiola spp.

\begin{tabular}{|c|c|c|}
\hline Plant species & Compound & References \\
\hline $\begin{array}{l}\text { R. crenulata (in } \\
\text { total over } 26 \\
\text { compounds) }\end{array}$ & $\begin{array}{l}\text { Salidroside and tyrosol, } 2 \text {-(4-hydroxyphenyl)-ethyl- } O \text { - } \\
\text { b-D-glucopyranosyl-6- } O \text { - } \beta \text {-D-glucopyranoside, } p \text { - } \\
\text { hydroxyphenacyl- } \beta \text {-D-glucopyranoside, icariside D2, } \\
\text { rutin, picein, lotaustralin, rodiocyanoside A, } \\
\text { crenulatin, rhodionin, rhodiosin, daucosterol, } \beta \text { - } \\
\text { sitosterol, hydroxycinnamic, gallic acid, creosides I, } \\
\text { II, III, IV, and V }\end{array}$ & $\begin{array}{l}\text { Wang and Wang (1992), Du and Xie (1995), Peng } \\
\text { et al. (1995), Su et al. (2007), Nakamura et al. } \\
\text { (2008), Chen et al. (2012) }\end{array}$ \\
\hline $\begin{array}{l}\text { R. kirilowii (in } \\
\text { total over } 49 \\
\text { compounds) }\end{array}$ & $\begin{array}{l}\text { Salidroside and tyrosol, rosin, rosavin, rosarin, cinnamyl } \\
\text { alcohol, herbacytrin, umbeliferon, esculetin, luteolin, } \\
\text { tricetin, epigallocatechin, epigallocatechin gallate, } \\
\text { lotaustralin, rodiocyanoside A, tannins, daucosterol } \\
\text { and } \beta \text {-sitosterol, hydroxycinnamic, gallic acid, } \\
\text { chlorogenic acid }\end{array}$ & $\begin{array}{l}\text { Kang et al. (1992), Krasnov et al. (1978), Krajewska- } \\
\text { Patan et al. (2006), Wiedenfeld et al. (2007b), Zuo } \\
\text { et al. (2007), Wong et al. (2008), Krajewska-Patan } \\
\text { et al. (2009), Krajewska-Patan et al. (2013) }\end{array}$ \\
\hline R. quadrifida & $\begin{array}{l}\text { Salidroside and tyrosol, rosin, rosavin, rosarin, cinnamyl } \\
\text { alcohol, rhodiooctanoside, rhodiolin, mongrhoside, } \\
\text { rhodiocyanosides A and B, rhodioflavonoside, } \\
\text { rhodiooctanoside, tricetin, } \\
\text { L-rhamnopyranoside, osmaronin, chlorogenic acid }\end{array}$ & $\begin{array}{l}\text { Yoshikawa et al. (1996), Altantsetseg et al. (2007), } \\
\text { Wiedenfeld et al. (2007a) }\end{array}$ \\
\hline $\begin{array}{l}R \text {. rosea (in total } \\
\text { over } 140 \\
\text { compounds) }\end{array}$ & $\begin{array}{l}\text { salidroside and tyrosol, rosin, rosavin, rosarin, cinnamyl } \\
\text { alcohol, epigallocatechin, epigallocatechin gallate, } \\
\text { lotaustralin, rodiocyanoside A, herbacetin, kaemferol, } \\
\text { rosiridol and rosaridin, daucosterol and } \beta \text {-sitosterol, } \\
\text { Rhodiolosid A- C, organic acids, tannins, waxes, fats, } \\
\text { proanthocyanidins, sachaliside, gallic, } \\
\text { hydroxycinnamic acid, acetylrodalgin and tricin }\end{array}$ & $\begin{array}{l}\text { Saratikov et al. (1967), Kurkin et al. (1985, 1986), } \\
\text { Kurkin and Zapesochnaya (1986), Akgul et al. } \\
\text { (2004), Yousef et al. (2006), Altantsetseg et al. } \\
\text { (2007), Ali et al. (2008), Ma et al. (2013) }\end{array}$ \\
\hline $\begin{array}{l}\text { R. sachalinensis } \\
\text { (in total over } 44 \\
\text { compounds) }\end{array}$ & $\begin{array}{l}\text { salidroside and tyrosol, rosarin, rosavin, cinnamyl } \\
\text { alcohol, multiflorin B, tricetin, afzelin, kaempferol, } \\
\text { rhodionin, rhodiosin, gallic acid, sachalosides I -V, } \\
\text { sacranoside A, rhodiocyanoside A, lotaustralin, } \\
\text { hetorodendrin, -glucopyranoside }\end{array}$ & $\begin{array}{l}\text { Lee et al. (2000), Nakamura et al. (2007), Zhang et al. } \\
\text { (2007a), Choe et al. (2012) }\end{array}$ \\
\hline
\end{tabular}

properties (Sokolov et al. 1985, 1990). Other investigations revealed immunostimulating and anticancer effects of rosavin (Zapesochnaya et al. 1995; Skopińska-Różewska et al. 2008b).

Therefore Rhodiola preparations may be therapeutically applied to humans, for preventing or treating disorders like neurodegenerative diseases, cerebral ischaemia, fatigue, hypoxia, diabetes, and cancer, among many others.

Phytochemical investigations of Rhodiola plants pointed out that the content of salidroside, rosin and its derivatives depends on the morphological part of the plant-higher in rhizomes than in roots (Przybył et al. 2008; Węglarz et al. 2008; Tasheva and Kosturkova 2010). It also depends on the age and sex of the plantrhizomes originated from male plants accumulated higher amounts of salidroside (Revina et al. 1976; Platikanov and Evstatieva 2008; Węglarz et al. 2008; Kucharski et al. 2011). Salidroside content in plants is also connected with the place and time of harvesting (Revina et al. 1976; Kurkin et al. 1985; Bykov et al. 1999; Buchwald et al. 2006) as well as place of plant origin (Altantsetseg et al. 2007; Węglarz et al. 2008). To date, the results from the papers concerning chemical profiling of Rhodiola plants demonstrated the higher salidroside and rosin and its derivatives content in plants collected from natural sources than derived from field cultivation (Table 2).

Research studies on Rhodiola species have been stimulated by their documented pharmacological properties. Recently a sharp increase in the demand for Rhodiola-based products has been observed worldwide which is connected with the necessity of a stable raw material supply and-at the same timeextensive collecting from natural sources. Rhodiola rosea is the most exploited species for commercial purposes. Due to the intensive collection, natural populations of $R$. rosea are highly threatened and 
Table 2 Content of salidroside, rosin and its derivatives (\% DW) in Rhodiola species

\begin{tabular}{|c|c|c|c|c|c|}
\hline \multirow[t]{2}{*}{ Genus } & \multicolumn{2}{|c|}{ Natural source } & \multicolumn{2}{|l|}{ Plantation } & \multirow[t]{2}{*}{ References } \\
\hline & $\begin{array}{l}\text { Salidroside } \\
\text { content }(\%)\end{array}$ & $\begin{array}{l}\text { Rosin and its } \\
\text { derivatives } \\
\text { content }(\%)\end{array}$ & $\begin{array}{l}\text { Salidroside } \\
\text { content }(\%)\end{array}$ & $\begin{array}{l}\text { Rosin and its } \\
\text { derivatives } \\
\text { content }(\%)\end{array}$ & \\
\hline $\begin{array}{l}\text { Rhodiola } \\
\text { crenulata }\end{array}$ & $0.1-2.05$ & Not detected & No data & No data & Abidov et al. (2003), Chen et al. (2012), \\
\hline $\begin{array}{l}\text { Rhodiola } \\
\quad \text { kirilowii }\end{array}$ & $0.32-2.5$ & Not detected & $0.0002-0.005$ & $\begin{array}{l}0.03 \text { (total } \\
\text { content of } \\
\text { rosin, rosavin, } \\
\text { rosarin) }\end{array}$ & $\begin{array}{l}\text { Krajewska-Patan et al. (2009), Tao et al. (2010), } \\
\text { Zhou et al. (2011), Gryszczynska et al. (2012) }\end{array}$ \\
\hline $\begin{array}{l}\text { Rhodiola } \\
\text { quadrifida }\end{array}$ & $0.016-0.45$ & $\begin{array}{l}\text { Rosin- } \\
0.26-0.31 \\
\text { Rosavin- } \\
0.19-0.76 \\
\text { Rosarin- } \\
0.26-1.1\end{array}$ & No data & No data & $\begin{array}{l}\text { Yoshikawa et al. (1996), Altantsetseg et al. } \\
\text { (2007), Wiedenfeld et al. (2007a) }\end{array}$ \\
\hline $\begin{array}{l}\text { Rhodiola } \\
\text { rosea }\end{array}$ & $0.14-1.76$ & $\begin{array}{l}\text { Rosin- } \\
0.1-0.31 \\
\text { Rosavin- } \\
0.4-3.7 \\
\text { Rosarin- } \\
0.08-1.1\end{array}$ & $0.14-1.6$ & $\begin{array}{l}\text { Rosin-0.36-0.53 } \\
\text { Rosavin-0. 9-5 } \\
\text { rosarin-0.16-0.3 }\end{array}$ & $\begin{array}{l}\text { Kurkin et al. (1985, 1986), Galambosi (2006), } \\
\text { Altantsetseg et al. (2007), Platikanov and } \\
\text { Evstatieva (2008), Bozhilova (2011), } \\
\text { Kołodziej and Sugier (2012), Peschel et al. } \\
\text { (2013), Saunders et al. (2013) }\end{array}$ \\
\hline $\begin{array}{l}\text { Rhodiola } \\
\quad \text { sachalinensis }\end{array}$ & $0.1-1.5$ & $\begin{array}{l}\text { Rosin-No } \\
\text { data } \\
\text { Rosavin- } \\
0.034 \\
\text { Rosarin- } \\
0.0097\end{array}$ & $0.1-0.5$ & No data & $\begin{array}{l}\text { Li et al. (2001), Yan et al. (2004), Nakamura } \\
\text { et al. (2007), Choe et al. (2012) }\end{array}$ \\
\hline
\end{tabular}

$D W$ dry weight

included in the list of endangered plant species in many countries (Russia, Great Britain, the Czech Republic, Bosnia and Herzegovina, vulnerable in Slovakia; in Bulgaria collection is strictly forbidden; in Poland $R$. rosea is only found in National Parks) (Galambosi 2006; Kołodziej and Sugier 2012). Sufficient yields of field-cultivated $R$. rosea roots/rhizomes could be obtained within 5-7 years of cultivation, however the costs are high (Galambosi 2006; Peschel et al. 2013). Another approach to provide a stable supply of the desired compound is its chemical synthesis. The chemical synthesis of rosavin, the accepted marker for genetically pure $R$. rosea and its extracts (Brown et al. 2002), was performed by Patov et al. 2006. In the case of salidroside the procedure of it synthesis in a multikilogram scale with $72 \%$ overall yield and $>98 \%$ purity has been developed recently by Shi et al. (2011). Nevertheless chemical synthesis seems not to be the solution in the case of Rhodiola preparations as it is obvious on the basis of pharmacological studies that salidroside and rosavins are not the only biologically active ingredients responsible for its efficacy and health benefits (Brown et al. 2002; Nan et al. 2003; Zuo et al. 2007; Panossian et al. 2010; Gupta et al. 2010; Choe et al. 2012; Wang et al. 2012; Chen et al. 2012).

Biotechnological methods offer the possibilities to produce useful compounds under controlled conditions independent of environmental changes and elaboration of scale-up procedures would reduce labour costs and improve productivity of secondary metabolites. Moreover, the cells and organs involved directly with the biosynthesis of compounds of interests could be cultivated and manipulated to enhance their production.

Numerous studies have revealed that the addition of an elicitor (microbial, physical, or chemical factors) or/and a precursor to the culture media significantly 
Table 3 Natural occurrence of Rhodiola species

\begin{tabular}{|c|c|c|}
\hline Genus & $\begin{array}{l}\text { Examples of } \\
\text { occurrence }\end{array}$ & References \\
\hline $\begin{array}{l}\text { Rhodiola } \\
\text { crenulata } \\
\text { (Hook. f. et } \\
\text { Thoms) H. } \\
\text { Ohba }\end{array}$ & Asia (Tibet, China) & $\begin{array}{l}\text { Wang and Wang } \\
\text { (1992), Peng et al. } \\
\text { (1995), Chen } \\
\text { et al. (2012) }\end{array}$ \\
\hline $\begin{array}{l}\text { Rhodiola } \\
\text { kirilowii } \\
\text { (Regel) Regel } \\
\text { et } \\
\text { Maximowicz }\end{array}$ & $\begin{array}{l}\text { Asia (Tibet- } \\
\text { Qinghai), Europe } \\
\text { (Poland) }\end{array}$ & $\begin{array}{l}\text { Komarov and } \\
\text { Juzepczyk (1939), } \\
\text { Krajewska-Patan } \\
\text { et al. (2008b) }\end{array}$ \\
\hline $\begin{array}{l}\text { Rhodiola } \\
\text { quadrifida } \\
\text { (Pall) Fish. } \\
\text { and May. }\end{array}$ & $\begin{array}{l}\text { Asia (China, Tibet, } \\
\text { Mongolia) }\end{array}$ & $\begin{array}{l}\text { Yoshikawa et al. } \\
\text { (1996), } \\
\text { Altantsetseg et al. } \\
\text { (2007), } \\
\text { Wiedenfeld et al. } \\
\text { (2007a) }\end{array}$ \\
\hline $\begin{array}{l}\text { Rhodiola rosea } \\
\text { L. }\end{array}$ & $\begin{array}{l}\text { Asia (China), North } \\
\text { America (USA, } \\
\text { Canada) Europe } \\
\text { (Russia, Poland, } \\
\text { Scandinavia, } \\
\text { Sweden) }\end{array}$ & $\begin{array}{l}\text { Galambosi (2006), } \\
\text { Panossian et al. } \\
\text { (2010), Hung } \\
\text { et al. (2011), } \\
\text { Kołodziej and } \\
\text { Sugier (2012), } \\
\text { Saunders et al. } \\
\text { (2013) }\end{array}$ \\
\hline $\begin{array}{l}\text { Rhodiola } \\
\text { sachalinensis } \\
\text { A }\end{array}$ & $\begin{array}{l}\text { Eastern Europe, Asia } \\
\text { (China, Korea) }\end{array}$ & $\begin{array}{l}\text { Lee et al. (2000), Li } \\
\text { and Chen (2001), } \\
\text { Yan et al. (2004) }\end{array}$ \\
\hline Bor & & \\
\hline
\end{tabular}

increases the production of secondary metabolites (Kolewe et al. 2008; Shilpa et al. 2010; Vijaya et al. 2010).

This review discusses the ways to enhance salidroside and rosin and its derivatives production in various types of in vitro cultures of Rhodiola spp. To date, to the in vitro cultures have been introduced mainly for $R$. rosea and selected Asian species, such as $R$. crenulata, $R$. kirilowii, $R$. quadrifida and $R$. sachalinensis. Table 3 presents the distribution of the species.

\section{Biosynthetic pathway of salidroside, rosin and its derivatives}

The biosynthetic pathway of the salidroside precursor L-tyrosol and its regulation are not completely understood. There are two different views in the literature concerning the production of salidroside. Both are

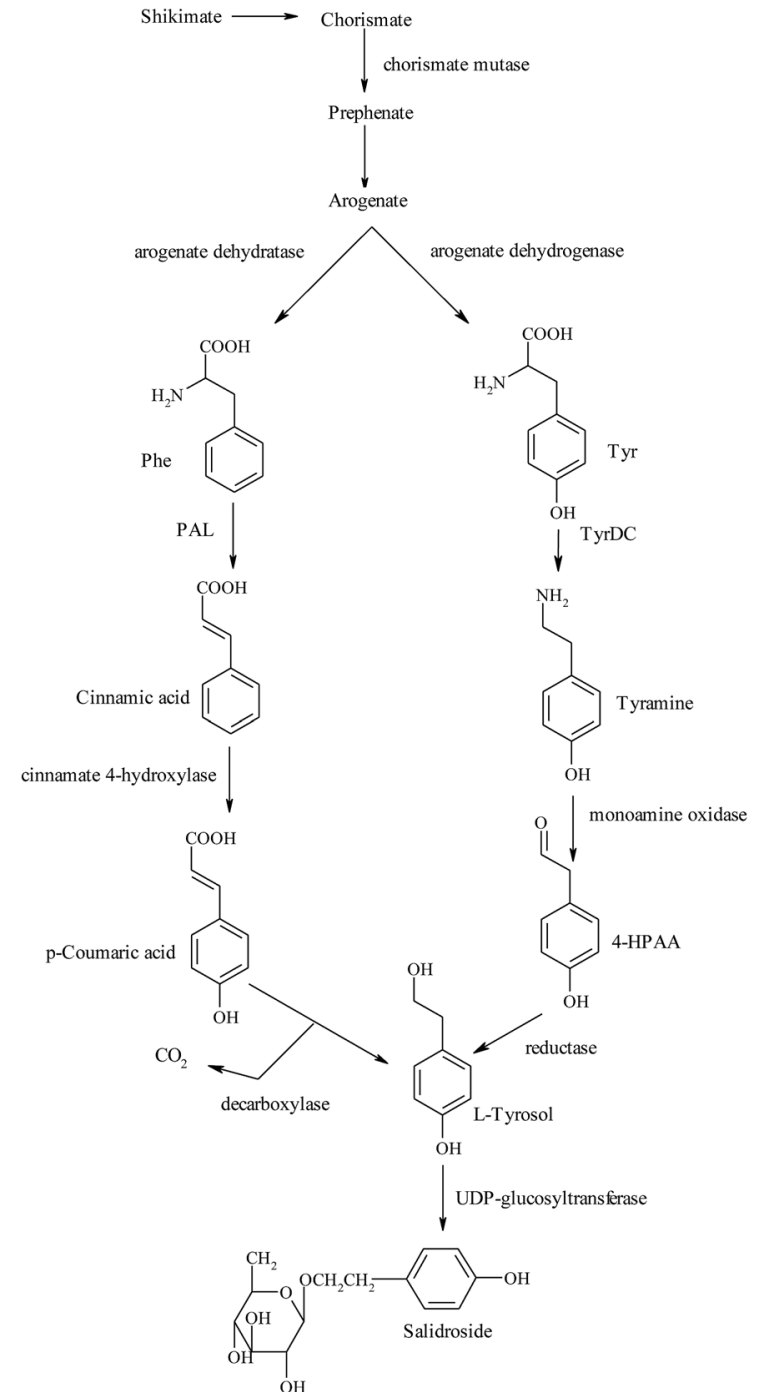

Fig. 1 Biosynthetic pathway of salidroside (Ma et al. 2008). Phe L-phenylalanine, Tyr L-tyrosine, PAL phenylalanine ammonia-lyase, TyrDC tyrosine decarboxylase, 4-HPAA 4-hydroxyphenylacetaldehyde

connected with the shikimate pathway producing L-phenylalanine or L-tyrosine (Yao et al. 1995). The first is that tyrosol is presumably produced by a decarboxylase from p-coumaric acid, which is mainly derived from L-phenylalanine (Xu and Su 1997). The second view states that the precursor of tyrosol may be tyramine, which is synthesized from tyrosine (Zhang et al. 2011) (Fig. 1).

In order to elucidate the molecular pathways involved in tyrosol biosynthesis Ma et al. (2008) analyzed the effect of overexpressing the endogenous 
PALrs1 gene in $R$. sachalinensis on the production of higher levels of p-coumaric acid and salidroside. The obtained results showed that overexpression of the PALrs1 gene resulted in a 3.3-fold increase of p-coumaric acid. However, the levels of tyrosine, tyrosol and salidroside were 2.6-fold, 4.7-fold and 7.7fold lower, respectively, in PALrs1 transgenic plants than in controls. Overexpression of the PALrs1 gene and accumulation of p-coumaric acid did not facilitate tyrosol biosynthesis. Thus, tyrosol probably is not derived from L-phenylalanine. Following the second view of salidroside biosynthesis Gyorgy et al. (2009) analyzed the expression of the $R$. rosea TyrDC gene encoding tyrosine decarboxylase. TyrDC expression was detected in leaves as well as in roots. The expression was significantly higher in roots, which coincides with the fact that salidroside accumulates preferentially in the underground parts of the plant. The expression was also higher in the line accumulating high levels of salidroside, compared to the line with lower salidroside content. Similar results were obtained by Zhang et al. (2011). In this study, a cDNA encoding TyrDC was isolated from $R$. sachalinensis and the effects of recombinant RsTyrDC and sense and antisense overexpression of endogenous RsTyrDC on tyrosol synthesis were investigated. For sense-RsTyrDC expression, RNA gel blotting indicated that RsTyrDC was over-expressed at transcriptional levels and TyrDC activity in the RsTyrDC transgenic lines was 74 and $127 \%$ higher, respectively, than in the empty vector-transformed control plants. This overexpression resulted in the accumulation of tyrosol and salidroside. Simultaneously there was evidence of reduced accumulation of the endogenous TyrDC transcripts of $R$. sachalinensis in the antisense plant.

Summarizing these research results, it is tempting to speculate that the biosynthesis of salidroside begins with the decarboxylation of tyrosine by TyrDC, which produces tyramine.

The production of rosin and its derivatives in Rhodiola is restricted to only a few species. Biosynthesis of phenolic glycosides occurs spontaneously in Rhodiola roots and rhizomes (Krajewska-Patan et al. 2013). According to György (2006) the cinnamyl alcohol glycosides are products of phenylpropanoid metabolism, derived from L-phenylalanine. Phenylalanine ammonia lyase (PAL) converts L-phenylalanine to cinnamic acid. From cinnamic acid cinnamyl-CoA ester is formed through hydroxycinnamate: CoA ligase (4CL). This CoA ester is reduced to cinnamaldehyde by cinnamyl-CoA reductase (CCR). The cinnamaldehyde is further reduced by cinnamyl alcohol dehydrogenase (CAD) to cinnamyl alcohol (Fig. 2). The enzymes that take part in the formation of the glycosides of cinnamyl alcohol are not yet described. By one glucose transfer rosin is formed, which is the simplest cinnamyl alcohol glycoside. From rosin rosavin is formed by adding an arabinopyranose unit and rosarin by adding an arabinofuranose unit. Further glycosides may be formed depending on the sugar type and the connection site.

\section{The enhancement of salidroside, rosin and its derivatives production in Rhodiola spp. in vitro cultures}

Biotechnology offers an opportunity to exploit cells, tissues, organs or entire plants by growing them in vitro and to genetically manipulate them to get the desired compounds (Rao and Ravishankar 2002). Till now the biotechnological production of salidroside using plant cell cultures derived from $R$. crenulata, $R$. rosea, $R$. kirilowii, $R$. quadrifida and $R$. sachalinensis have been investigated. The influence of external factors such as nutrient levels, stress factors, light and growth regulators on salidroside and rosavins accumulation is summarized in Table 4.

\section{The effect of growth regulators}

Enhanced salidroside accumulation in $R$. sachalinensis compact callus aggregate culture (CCA) was observed by $\mathrm{Xu}$ et al. (1998c) compared to dispersed cells. The CCA were maintained on MS medium supplemented with $3 \%$ sucrose, $0.3 \mathrm{mg} / \mathrm{l} \mathrm{NAA}$, and $3 \mathrm{mg} / \mathrm{l} \mathrm{BA}$. The salidroside yield in CCA after 24 days of culture was $6.8 \mathrm{mg} / \mathrm{g} \mathrm{DW}$ and, approximately six times as much as that of the dispersed cells; the growth rate of CCA was comparable to that of the dispersed cells. Furthermore, the suitability of airlift reactors for large-scale culture of CCA was investigated in a 5-1 airlift reactor. The salidroside amount was similar to that of shake-flask cultures though the biomass was relatively low. Xu et al. (1999) estabished liquid cultures of compact callus aggregates (CCA) of 
Fig. 2 Biosynthetic pathway of rosin, rosavin and rosarin (György 2006)

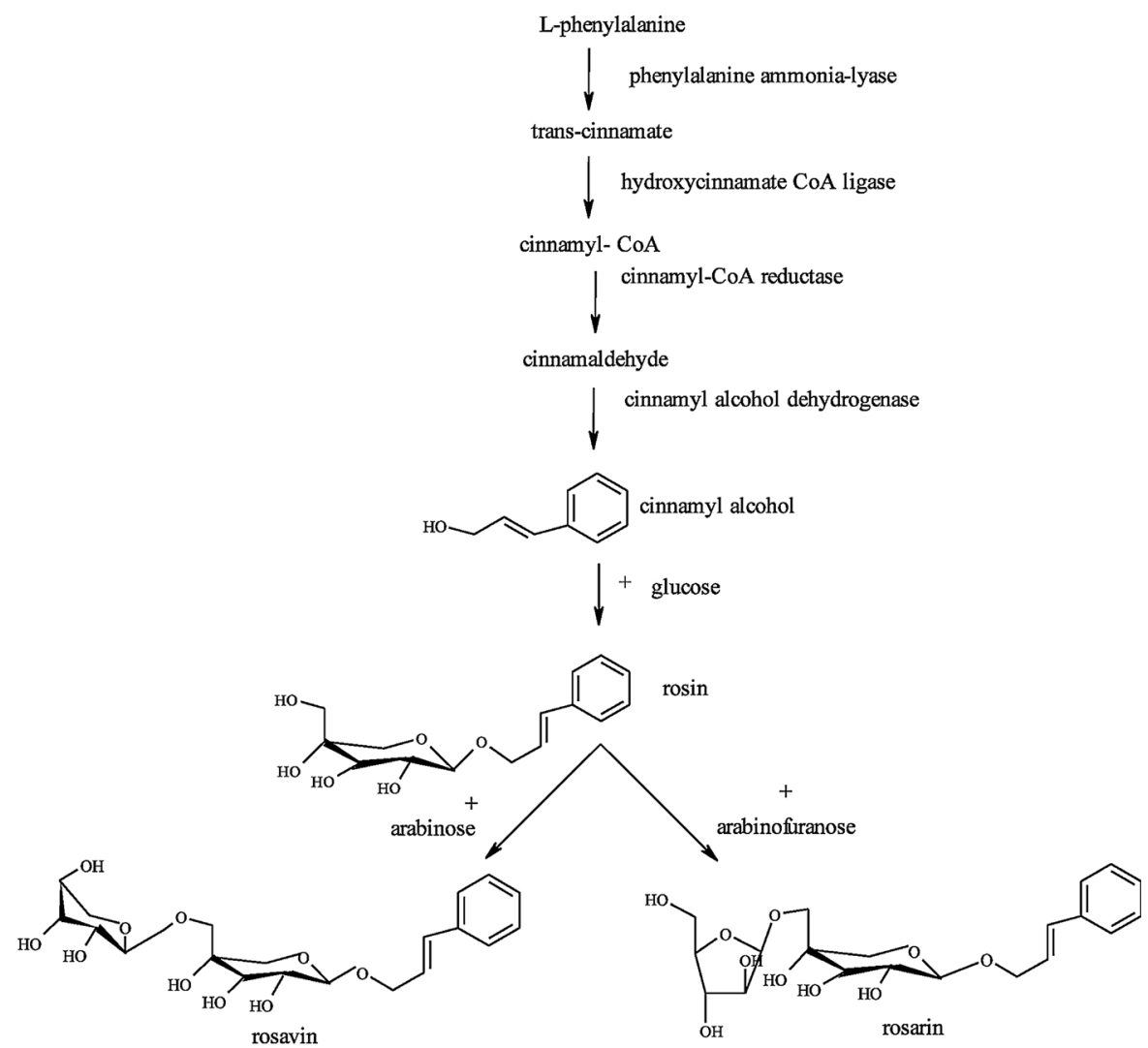

R. sachalinensis derived from stems, and found that a higher cytokinin/auxin ratio was beneficial for both CCA growth and salidroside accumulation. The maximum salidroside yield of $4.7 \mathrm{mg} / \mathrm{g}$ DW was achieved when MS medium was supplemented with $0.2 \mathrm{mg} / \mathrm{l}$ NAA and $3.3 \mathrm{mg} / \mathrm{l} \mathrm{BA}$. Also a favourable effect on the metabolite productivity of raising the initial sucrose levels has been observed. The authors indicated that for growth and salidroside accumulation (up to $7.9 \mathrm{mg} / \mathrm{g} \mathrm{DW}$ ) the CCA culture should be cultivated in MS medium containing $40 \mathrm{~g} / \mathrm{l}$ of sucrose, $0.2 \mathrm{mg} / \mathrm{l}$ NAA and $3.3 \mathrm{mg} / \mathrm{l} \mathrm{BA}$. A compact callus aggregate culture (initiated from callus established from cotyledons) of $R$. sachalinensis reached a high yield of salidroside under appropriate culture conditions. A significant increase in salidroside content (up to $10.78 \mathrm{mg} / \mathrm{g} \mathrm{DW}$ ) was obtained when the inoculum amount was $10 \%$ and the concentration of BA and IBA added to the liquid medium was 5 and $2.5 \mathrm{mg} / \mathrm{l}$, respectively. The addition of 2,4-D at a concentration of $2.0 \mathrm{mg} / \mathrm{l}$ boosted the salidroside accumulation in the treated cells to $41.94 \mathrm{mg} / \mathrm{g}$ DW while the addition of kinetin inhibited both salidroside accumulation and growth of the CCA suspension culture $(\mathrm{Wu}$ et al. 2003).

Callus tissue of $R$. crenulata was initiated from three types of explants: leaf, stem and root, that were maintained on half strength MS medium supplemented with $3.0 \mathrm{mg} / \mathrm{l} \mathrm{NAA}$ and $0.5 \mathrm{mg} / \mathrm{l} \mathrm{BA}$. Callus initiation was noticeably faster on leafy explants (within 9 days from the beginning of culture) compared to stems and roots (13 and 15 days, respectively). For callus subcultures and subsequent cell suspension cultures full strength MS containing $0.5 \mathrm{mg} / \mathrm{l} \mathrm{TDZ}$ (thidiazuron) and $0.5 \mathrm{mg} / \mathrm{l} \mathrm{NAA}$ proved to be the best. The average salidroside content in cell suspension culture reached $26.48 \mathrm{mg} / \mathrm{g}$ DW (Shi et al. 2013).

A callus culture of $R$. kirilowii obtained by Krajewska-Patan et al. (2009) also produced salidroside. Two lines of callus tissue were initiated. The first started from cotyledons on MS medium supplemented with BAP $2.0 \mathrm{mg} / \mathrm{l}$, adenine chloride $1.0 \mathrm{mg} / \mathrm{l}$ and NAA $2.0 \mathrm{mg} / \mathrm{l}$. The second started from hypocotyles 
Table 4 Salidroside, rosin and its derivatives production in plant cell, tissue and organ cultures of selected Rhodiola spp.

\begin{tabular}{|c|c|c|c|c|c|}
\hline Plant species & Culture type & Medium & Growth regulators & Product & References \\
\hline \multirow[t]{2}{*}{ R. crenulata } & \multirow[t]{2}{*}{$\begin{array}{l}\text { Callus culture and cell } \\
\text { suspension culture }\end{array}$} & MS & $3.0 \mathrm{mg} / 1 \mathrm{NAA}, 0.5 \mathrm{mg} / \mathrm{l} \mathrm{BA}$ & \multirow[t]{2}{*}{$\begin{array}{l}\text { Salidroside }(26.48 \mathrm{mg} / \mathrm{g} \\
\text { DW) }\end{array}$} & \multirow[t]{2}{*}{ Shi et al. (2013) } \\
\hline & & MS & $\begin{array}{l}0.5 \mathrm{mg} / \mathrm{l} \mathrm{TDZ}, 0.5 \mathrm{mg} / \mathrm{l} \\
\mathrm{NAA}\end{array}$ & & \\
\hline R. kirilowii & Callus culture & MS & $\begin{array}{l}2.0 \mathrm{~g} / 1 \mathrm{BA}, 1.0 \mathrm{~g} / 1 \text { adenine } \\
\text { chloride, } 2.0 \mathrm{~g} / 1 \mathrm{NAA} \text { or } \\
\text { 2,4-D }\end{array}$ & $\begin{array}{l}\text { Salidroside }(0.16 \mathrm{mg} / \mathrm{g} \\
\text { DW) }\end{array}$ & $\begin{array}{l}\text { Krajewska-Patan } \\
\text { et al. (2009) }\end{array}$ \\
\hline R. quadrifida & Callus culture & MS & 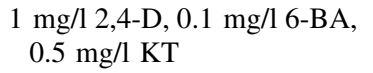 & $\begin{array}{l}\text { Salidroside }(2.8 \mathrm{mg} / \mathrm{g} \\
\text { DW) }\end{array}$ & $\begin{array}{l}\text { Sheng et al. } \\
\text { (2005) }\end{array}$ \\
\hline \multirow[t]{4}{*}{ R. rosea } & $\begin{array}{l}\text { Shoots and rooted } \\
\text { plantlets culture }\end{array}$ & NN & $\begin{array}{l}0.01 \mathrm{mg} / 1 \mathrm{NAA} \text { and } 0.1 \mathrm{mg} / 1 \\
\text { IAA }\end{array}$ & $\begin{array}{l}\text { Salidroside } \\
\text { Rosin and its derivatives } \\
\text { (content not showed) }\end{array}$ & $\begin{array}{l}\text { Furmanowa et al. } \\
\text { (1995) }\end{array}$ \\
\hline & Callus culture & MS & $\begin{array}{l}2 \mathrm{mg} / 1 \mathrm{BAP}, 2 \mathrm{mg} / \mathrm{l} \mathrm{NAA}, \\
1 \mathrm{~g} / \mathrm{l} \text {, casamino acids }\end{array}$ & $\begin{array}{l}\text { Salidroside } \\
\text { Rosin and its derivatives } \\
\text { (content not showed) }\end{array}$ & $\begin{array}{l}\text { Furmanowa et al. } \\
\text { (1998) }\end{array}$ \\
\hline & Shoot culture & MS & $2 \mathrm{mg} / \mathrm{l}$ zeatin or $2 \mathrm{mg} / \mathrm{BA}$ & Salidroside $(5.3-6.4 \mathrm{mg} / \mathrm{g}$ & Tasheva and \\
\hline & Rooting induction & $1 / 2 \mathrm{MS}$ & $2 \mathrm{mg} / 1 \mathrm{IBA}, 0.2 \mathrm{mg} / 1 \mathrm{IAA}$ & DW) & $\begin{array}{l}\text { Kosturkova } \\
\text { (2010) }\end{array}$ \\
\hline $\begin{array}{l}R . \\
\text { sachalinensis }\end{array}$ & $\begin{array}{l}\text { Compact callus } \\
\text { aggregate culture }\end{array}$ & MS & $0.3 \mathrm{mg} / \mathrm{l} \mathrm{NAA,} 3 \mathrm{mg} / \mathrm{l} \mathrm{BA}$ & $\begin{array}{l}\text { Salidroside }(6.8 \mathrm{mg} / \mathrm{g} \\
\text { DW) }\end{array}$ & Xu et al. (1998c) \\
\hline $\begin{array}{l}R . \\
\quad \text { sachalinensis }\end{array}$ & $\begin{array}{l}\text { Compact callus } \\
\text { aggregate culture } \\
\text { Callus culture } \\
\text { Compact callus } \\
\text { aggregate culture }\end{array}$ & $\begin{array}{l}\text { MS } \\
\text { MS } \\
\text { MS }\end{array}$ & $\begin{array}{l}0.2 \mathrm{mg} / \mathrm{l} \mathrm{NAA}, 3.3 \mathrm{mg} / \mathrm{l} \mathrm{BA} \text {, } \\
40 \mathrm{~g} / \mathrm{l} \text { of sucrose } \\
5 \mathrm{mg} / 1 \mathrm{BA}, 2 \mathrm{~m} / 1 \mathrm{IBA} \\
5 \mathrm{mg} / 1 \mathrm{BA}, 2.5 \mathrm{mg} / 1 \mathrm{IBA} \\
2.0 \mathrm{mg} / 12,4-\mathrm{D}\end{array}$ & $\begin{array}{l}\text { Salidroside }(7.9 \mathrm{mg} / \mathrm{g} \\
\text { DW) } \\
\text { Salidroside }(5.09 \mathrm{mg} / \mathrm{g} \\
\text { DW) } \\
\text { Salidroside }(41.94 \mathrm{mg} / \mathrm{g} \\
\text { DW) }\end{array}$ & $\begin{array}{l}\text { Xu et al. (1999) } \\
\text { Wu et al. (2003) }\end{array}$ \\
\hline
\end{tabular}

$D W$ dry weight

cultivated on MS supplemented with $1.0 \mathrm{mg} / 1$ 2,4-D. The results of phytochemical analyses revealed that callus tissues cultivated on solid medium produced the complete spectrum of active compounds characteristic for the roots of the plant. The highest salidroside content of $0.166 \mathrm{mg} / \mathrm{g}$ DW was observed in the line obtained from cotyledones.

An investigation concerning the effect of plant growth regulators on the induction and proliferation of callus of Rhodiola quadrifida was conducted on MS medium. The medium containing $1 \mathrm{mg} / 1$ 2,4-D, $2 \mathrm{mg} / 1$ NAA, $0.5 \mathrm{mg} / \mathrm{l} \mathrm{BAP}$ and $0.1 \mathrm{mg} / \mathrm{l}$ kinetin proved to be the best for induction of the callus from $R$. quadrifida (the induction rate was $83.3 \%$ ). The optimized combination of plant growth regulators for callus subculture was $1 \mathrm{mg} / \mathrm{l} 2,4-\mathrm{D}, 0.1 \mathrm{mg} / \mathrm{l} \mathrm{BAP}$ and $0.5 \mathrm{mg} / \mathrm{l}$ kinetin. When the callus was cultured in the optimum medium for 30 days the salidroside content reached $2.8 \mathrm{mg} / \mathrm{g}$ DW (Sheng et al. 2005).
Furmanowa et al. (1995) reported the micropropagation of $R$. rosea by apical and axillary meristems. Out of many combinations of growth regulators added to different basal media the best for shoot development were $0.1 \mathrm{mg} / \mathrm{l}$ kinetin and $0.1 \mathrm{mg} / \mathrm{l} \mathrm{IAA}$ added to $\mathrm{NN}$ medium (Nitsch and Nitsch 1969). The shoots were rooted on the same medium. In the shoots growing in vitro traces of salidroside, rosin and its derivatives were found. In further studies Furmanowa et al. (1998) described the condition for induction and maintenance of $R$. rosea callus cultures. Green callus tissue was formed from leaf segments on MS medium containing $2 \mathrm{mg} / \mathrm{l} \mathrm{BAP,} 2 \mathrm{mg} / \mathrm{l} \mathrm{NAA}, 1 \mathrm{~g} / \mathrm{l}$ casamino acids and $6 \%$ sucrose. Following four passages, callus was subcultured on new media with various combinations of auxins and cytokinins to find the best growth promoting conditions. Two lines were obtained: deep green and yellow. The phytochemical analyses revealed that only one green line produced salidroside, 


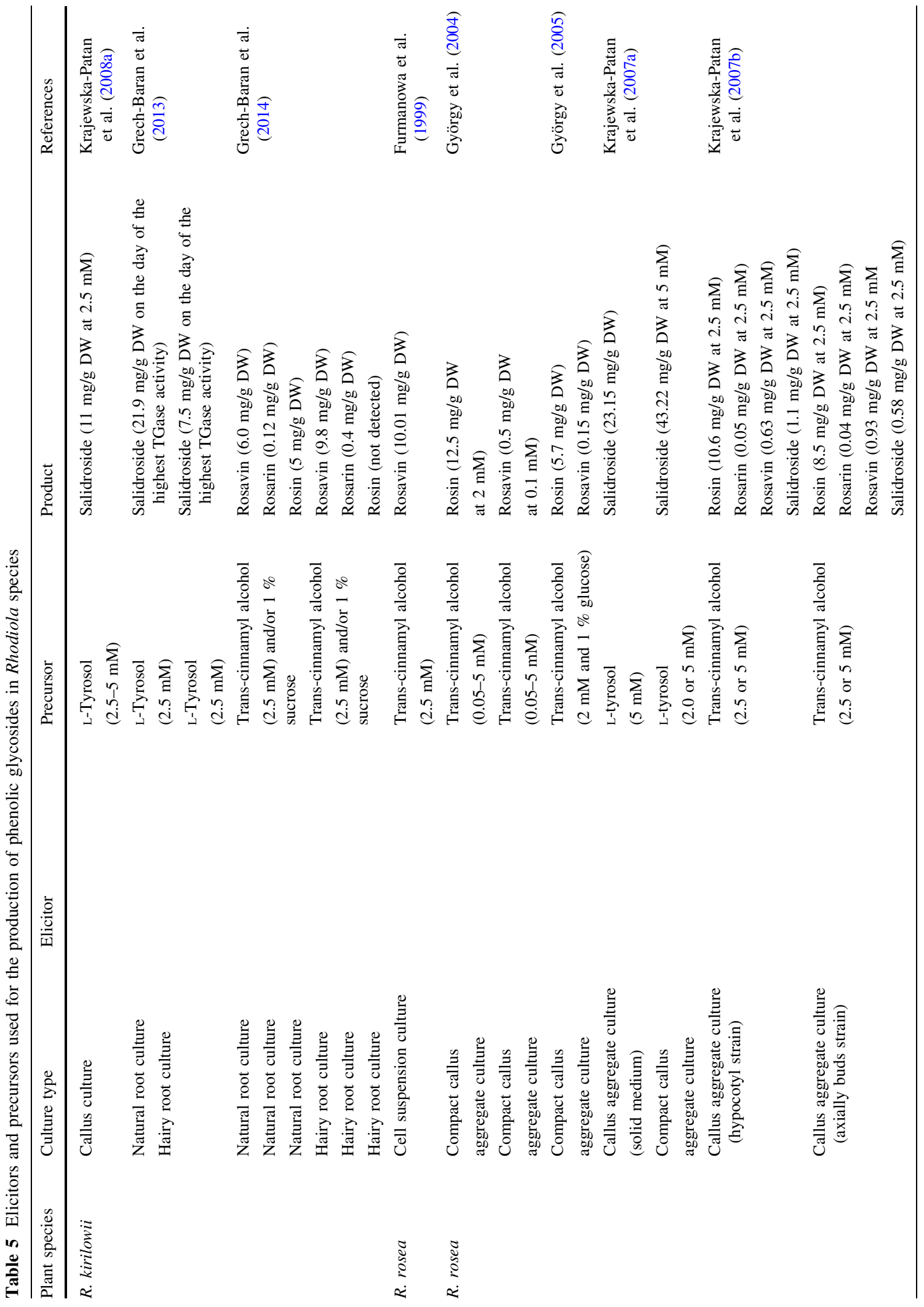




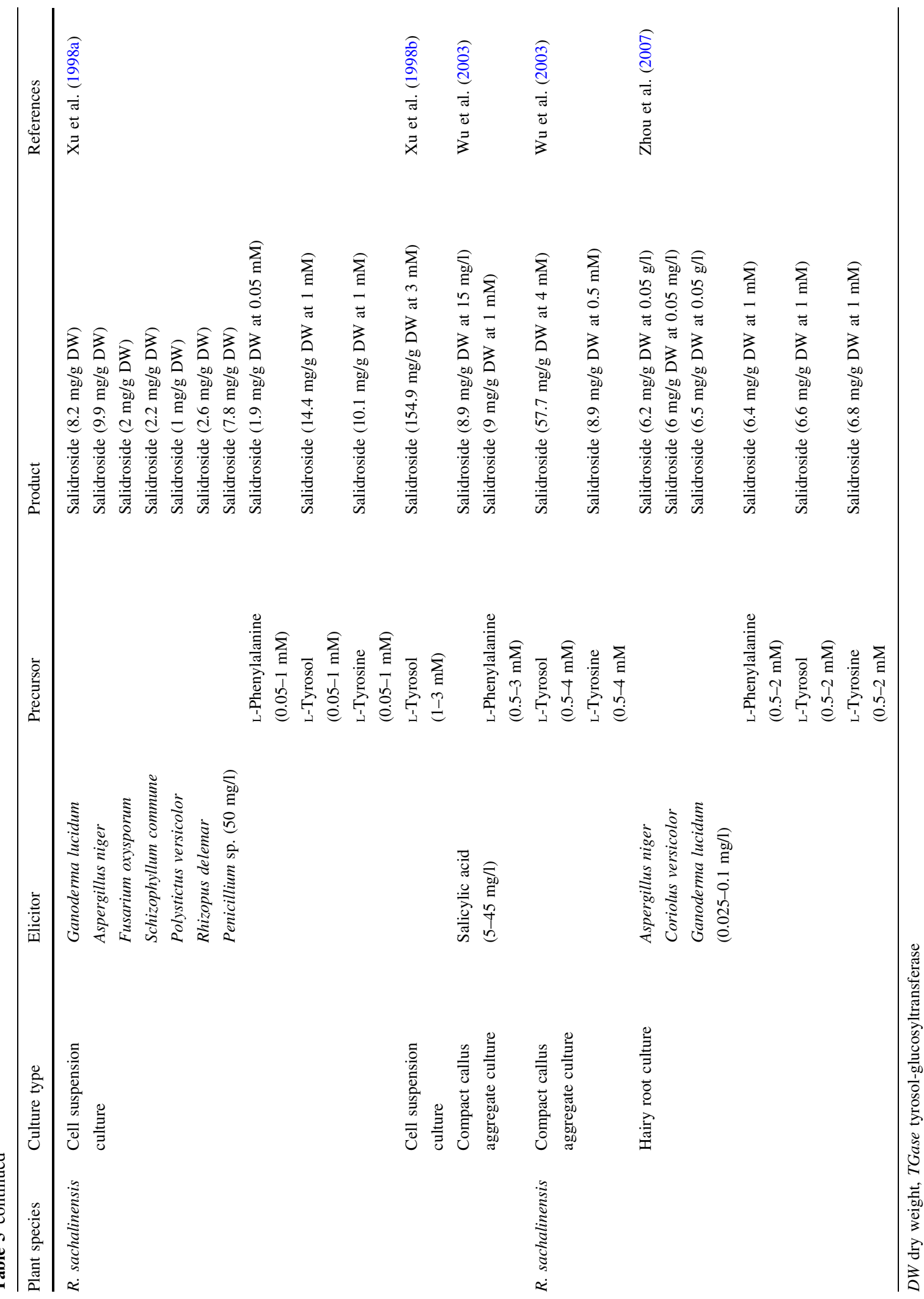


however, traces of rosin and its derivatives were present in all three types of investigated tissues.

In vitro cultures for micropropagation and the reintroduction of $R$ rosea were established by Tasheva and Kosturkova (2010). The authors reported that the best shoot induction was obtained from seedling explants on media containing $2 \mathrm{mg} / \mathrm{l}$ zeatin or BA each. Efficient rooting was induced on half-strength MS containing $2 \mathrm{mg} / \mathrm{l} \mathrm{IBA}$ and stimulated by adding $0.2 \mathrm{mg} / \mathrm{l}$ IAA. Regenerants rooted in perlite, peat, and soil (1:1:2), adapted in a greenhouse, and transplanted in the mountains survived $(70 \%)$ and developed similarly to the wild plants. The salidroside content of these plants after one or 2 years reached 6.4 and $6.1 \mathrm{mg} / \mathrm{g}$ DW in rhizomes and 6.2 and $5.3 \mathrm{mg} / \mathrm{g}$ DW in roots.

\section{Precursor feeding and elicitation}

Plant cells are structures accumulating many chemical compounds that take part in biochemical pathways of growth, defense, and survival. However, plant secondary metabolites often occur in plants in very small amounts, less than $1 \%$ of dry weight (OksmanCaldentey and Inze 2004). Hence, biotechnology offers an opportunity to exploit the cells, tissues, organs or entire organisms by growing them in vitro and to genetically manipulate them to obtain the desired compounds (Ramachandra Rao and Ravishankar 2002).

Elicitation and precursor feeding in Rhodiola spp. were reported by Xu et al. (1998a), using $R$. sachalinensis cell suspension cultures. Among the examined elicitors, one extracted from Aspergillus niger was the most effective for salidroside production which reached up to $9.9 \mathrm{mg} / \mathrm{g}$ DW. In comparison untreated cultures produced only $1.7 \mathrm{mg} / \mathrm{g}$ DW of salidroside. The applied precursor feeding strategy revealed that a significantly high level of salidroside $14.4 \mathrm{mg} / \mathrm{g} \mathrm{DW}$ was obtained when tyrosol was added to the medium. The combined application of both precursor and elicitor feeding resulted in a markedly high salidroside content of $17.3 \mathrm{mg} / \mathrm{g}$ DW (Xu et al. 1998a). Table 5 summarizes studies on elicitors and precursors applications for the production of phenolic glycosides in different Rhodiola spp.

In further studies, Xu et al. (1998b) showed that the biotransformation reaction depends not only on precursor addition, but also on the enzyme activities present in the cell suspension culture of $R$. sachalinensis. The relevant enzymes are classified as glucosyltransferases. The authors presented the effect of the tyrosol-glucosyltransferase (TGase) activity on tyrosol conversion to salidroside. The studies revealed that the low yield of salidroside in the cell culture of $R$. sachalinensis was connected with the low efficiency of glucosylation and non-synchronization between the TGase activity and tyrosol accumulation in cells. The highest TGase activity was found to be in the exponential growth phase on day 8. By repeated addition $3 \mathrm{mM}$ tyrosol at $24 \mathrm{~h}$ intervals, starting on the day of the highest TGase activity, a significant salidroside yield of $154.5 \mathrm{mg} / \mathrm{g}$ DW was obtained (Xu et al. 1998b). To date, that investigation has produced the highest intracellular content of salidroside obtained through biotransformation by $R$. sachalinensis in vitro cultures.

The low efficiency of glucosylation and the lack of synchronization between TGase activity with tyrosol appearance are believed to be the main cause for low salidroside yield in cell suspension cultures of $R$. sachalinensis ( $\mathrm{Xu}$ et al. 1998b). These findings prompted Ma et al. (2007) to research on glucosyltransferases on the molecular level. The putative UDP-glucose:tyrosol glucosyltransferase (UGT) cDNA UGT73B6 was isolated and it was also indicated that it exists in a single copy in the $R$. sachalinensis genome. Moreover UGT73B6 transcripts were more abundant in roots and callus than in stems and barely detected in leaves. The detected transcript levels were well correlated with the salidroside content where higher amounts of salidroside were found in roots and callus than in stems and leaves. Next UGT73B6 was successfully transferred into $R$. sachalinensis by Agrobacterium tumefaciens. Overexpression of the $U G T 73 B 6$ gene resulted in an evident increase of salidroside content up to 2- and 2.4-fold in transgenic plants and transgenic calli, respectively, compared with the untransformed controls. These results suggested the role of UGT73B6 in the conversion of tyrosol to salidroside in $R$. sachalinensis. However, UGT73B6 expression was scarcely detectable in leaves with unchanged salidroside content which indicated the possibility that other UDPglucosyltransferases might exist.

Further examinations lead to the isolation of two glucosyltransferase genes/cDNAs from roots and cells 
of $R$. sachalinensis cultured in the presence of methyl jasmonate: UGT72B14 and UGT74RI (Yu et al. 2011). The transcripts of the former glucosyltransferase was more abundant in roots, while the latter glucosyltransferase was highly expressed in callus tissue. The relative activity of recombinant UGT72B14, UGT74R1 and UGT73B6 was investigated revealing the highest relative rates towards tyrosol, salicylic acid and p-coumaric acid, respectively. The overexpression of UGT72B14, UGT74R1 and $U G T 73 B 6$ in hairy roots established with $A$. rhizogenes resulted in salidroside contents of about 19.81, 5.72 and $8.76 \mathrm{mg} / \mathrm{g}$ DW, respectively. Moreover, as expected the UGT73B6 hairy roots were capable of producing higher amounts of salidroside in comparison to $U G T 73 B 6$ transgenic plants or callus tissue reported by Ma et al. (2007).

The activity of tyrosol-glucosyltransferase (TGase) and the efficiency of salidroside production through biotransformation in natural and transformed root cultures of $R$. kirilowii were investigated by GrechBaran et al. (2013). To induce the TGase activity, tyrosol $2.5 \mathrm{mM}$ was added to natural and transformed root cultures on the day of inoculation. The first peak in TGase activity of $0.23 \mathrm{U} / \mu \mathrm{g}$ was detected on day 9 in the natural root culture, which correlated with the highest salidroside content of $15.8 \mathrm{mg} / \mathrm{g}$ DW. However, the highest TGase activity of $0.26 \mathrm{U} / \mu \mathrm{g}$ was noted on day 15. In the transformed root culture, on day 18 the highest TGase activity of $0.15 \mathrm{U} / \mu \mathrm{g}$, was observed and coincided with the highest salidroside content of $2.4 \mathrm{mg} / \mathrm{g}$ DW. These findings prompted us to carry out supplementation of cultures with tyrosol on the days of the previously detected highest activity of TGase. The applied strategy resulted in a notable increase of salidroside production of up to $21.9 \mathrm{mg} / \mathrm{g}$ DW and $7.5 \mathrm{mg} / \mathrm{g}$ for the natural and transformed root cultures, respectively.

Wu et al. (2003) described the feeding of salicylic acid (SA) (a signaling compound acting in response to stress factors), L-phenylalanine (Phe), L-tyrosine (Tyr), L-tryptophan (Trp), and L-tyrosol in suspensions of compact callus aggregate (CCA) cultures of $R$. sachalinensis. Each precursor or SA was added during the callus inoculation time. The results implied that feeding of Trp did not increase the salidroside yield; nevertheless, the addition of SA, Phe, and Tyr at a concentration of below $15 \mathrm{mg} / \mathrm{L}$ increased the salidroside content slightly. Supplementation with tyrosol at a concentration of $4 \mathrm{mM}$ resulted in a boosted production of salidroside up to $57.7 \mathrm{mg} / \mathrm{g}$ DW.

The approach of tyrosol addition into CCA cultures of $R$. rosea was also described by Krajewska-Patan et al. (2007a). The most pronounced results seen after the biotransformation were with the use of $5 \mathrm{mM}$ tyrosol. The salidroside content obtained was comparable to the results described above for the $R$. sachalinensis CCA culture.

Upon the challenge for increasing the secondary metabolite accumulation, Agrobacterium rhizogenes has been used for the induction of transgenic root cultures. Transformed root cultures are gaining increasing attention because of their fast growth, and genetic and biochemical stabilities (Giri et al. 2001). Thus, the biotransformation possibility in transformed root cultures of $R$. sachalinensis was studied by Zhou et al. (2007). The use of elicitors (Aspergillus niger, Coriolus versicolor, Ganoderma lucidum) and precursors (L-tyrosol, L-tyrosine, and L-phenylalanine) resulted in a significant increase of salidroside content, from $4.2 \mathrm{mg} / \mathrm{g}$ DW in the control to as much as $6.5 \mathrm{mg} / \mathrm{g}$ DW and $6.8 \mathrm{mg} / \mathrm{g}$ DW after treatment with the Ganoderma lucidum or L-tyrosine, respectively. The optimal concentration for elicitor and precursor in the liquid medium was $0.05 \mathrm{mg} / \mathrm{l}$ and $1.0 \mathrm{mM}$, respectively.

With the aim of enhancing the level of rosin and its derivatives through biotransformation in $R$. rosea cell suspension cultures, Furmanowa et al. (1999) measured the glycosylation level of exogenously applied trans-cinnamyl alcohol (CA) $2.5 \mathrm{mM}$. More than $90 \%$ of the trans-cinnamyl alcohol, used as the substrate for biotransformation, was converted by cells of $R$. rosea to a number of constituents, including rosavin of up to $10.01 \mathrm{mg} / \mathrm{g} \mathrm{DW}(1 \%)$ of cell DW within $72 \mathrm{~h}$. In studies involving $R$. rosea compact callus aggregate liquid culture, György et al. (2004) observed that optimal concentration of CA was $2 \mathrm{mM}$ for rosin production with a yield of $12.5 \mathrm{mg} / \mathrm{g}$ DW. The highest rosavin amount of $0.83 \mathrm{mg} / \mathrm{g}$ DW was determined at the presence of $0.1 \mathrm{mM} \mathrm{CA}$. Moreover, no rosarin was detected. Furthermore, the authors investigated the possibility of increasing the yield of biotransformation products by adding glucose to the culture medium (György et al. 2005). When the CCA liquid cultures were supplemented with $10 \mathrm{~g}$ glucose and $2 \mathrm{mMCA}$, the rosin content increased to $5.7 \mathrm{mg} / \mathrm{g}$ DW, and 4 new unexpected compounds related to 
rosin derivatives were detected. Nevertheless, the rosavin yield was still very low and reached a top concentration of only $0.02 \% \mathrm{DW}$.

In order to investigate the biotransformation capacity of $R$. rosea CCA on solid medium CA was added at a concentration of $2.5 \mathrm{mM}$ or $5 \mathrm{mM}$ (KrajewskaPatan et al. 2007b). It is worth pointing out that the CCA maintained on solid medium produced the whole spectrum of active compounds present in the intact plant: salidroside, tyrosol, rosin and its derivatives, chlorogenic and gallic acids. The highest obtained rosin amount was $10.6 \mathrm{mg} / \mathrm{g}$ DW. Similar to prior studies, rosavin and rosarin were produced in low amounts.

During our investigation, we compared the rosin and its derivatives production by biotransformation in $R$. kirilowii natural and hairy root cultures (GrechBaran et al. 2014). The obtained results confirmed that the addition of $2.5 \mathrm{mM}$ exogenous CA enabled rosarin, rosavin, and rosin production in natural root culture and rosarin and rosavin production in hairy root culture. Approximately 80 and $95 \%$ of the glycosides were released into the medium for natural and hairy root cultures, respectively. The highest intracellular rosavin yield $9.8 \mathrm{mg} / \mathrm{g} \mathrm{DW}$ and total (intracellular + extracellular) $\quad 505 \mathrm{mg} / \mathrm{l}$, was observed in hairy root culture when cinnamyl alcohol was applied on the day of inoculation with the addition of sucrose on the 14th day of culture. For rosin production, supplementation with CA alone on day 14 was more favourable with the highest intracellular amount $5 \mathrm{mg} / \mathrm{g}$ DW in natural root culture. Only traces of rosarin were detected.

\section{Conclusions}

The discovery of multiple pharmacological activities of Rhodiola plants, in the majority $R$. rosea, and the increasing demand for Rhodiola preparations led to extensive research on the chemical profiling of the Rhodiola extracts and searching for a stable supply for plant material. The biological properties of Rhodiola extracts were initially attributed to the presence of salidroside which was first isolated from Salix triandra in 1926 (Brown et al. 2002). Salidroside could be produced synthetically on the multikilogram scale (Shi et al. 2011) or could be obtained in amounts which often exceeded its content in Rhodiola plants from other botanical families i.e. Salicaceae, Ericaeceae. But salidroside proved not to be the only active component of the extracts. Apart from salidroside: rosavin, rosin and rosarin were believed to be important for the pharmacological effects of Rhodiola extracts. Further detailed chemical examination of Rhodiola extracts revealed approximately 140 compounds from different chemical groups exerting a variety of pharmacological activities (Panossian et al. 2010). Moreover the superior efficacy of total Rhodiola extract to its single ingredients was demonstrated (Sokolov et al. 1985, 1990; Skopińska-Różewska et al. 2008b).

Nowadays nearly all raw plant material comes from natural resources, areas with short vegetative seasons and low temperatures. The intensive collection of plants for commercial purposes is connected with the excessive exploitation of natural populations which have become threatened with extinction (Brown et al. 2002; Galambosi 2006; Kolodziej and Sugier 2012; Peschel et al. 2013).

To meet the increasing need for Rhodiola plants $R$. rosea was introduced to the field cultivation in Russia, Poland, Germany, Sweden and Finland (Galambosi 2006; Kolodziej and Sugier 2012), R. kirilowii in Poland (Krajewska-Patan et al. 2009) and R. sachalinens in northern China, however in the latter case it was reported that cultivated plants were very sensitive to root rotting diseases (Meng et al. 1994; Xu et al. 1999). Moreover, plants cultivated in the fields require at least 5-7 years to be ready for harvest and to achieve a composition comparable to the plants gathered from natural populations (Galambosi 2006; Kołodziej and Sugier 2012).

On the basis of available data in plants of $R$. crenulata, $R$. kirilowii, $R$. quadrifida, $R$. rosea and $R$. sachalinensis higher salidroside content was determined in plants collected from natural sources than those derived from field cultivation. The highest salidroside amount was detected in wild plants of $R$. kirilowii $(2.5 \%)$. However, there is no available data on $R$. crenulata and $R$ quadrifida field cultivation.

Plant biotechnology offers the opportunity to obtain plant material containing the desired compounds, often in higher amounts than the mother plant. Moreover plant collection to initiate in vitro cell and/ or organ cultures could be performed with respect to the actual laws protecting endangered species. The specific organ or tissue connected with the 
biosynthesis could be maintained in in vitro cultures to achieve the highest production of compounds of interest. Among the various biotechnological strategies applied to enhance salidroside accumulation in Rhodiola cell, and organ cultures the precursor feeding approach seemed to be the most efficient. In $R$. sachalinensis cell suspension cultures the salidroside content was ten times higher than in plants collected from natural sources. While the addition of growth regulators alone to the in vitro cultures did not result in a significant increase in salidroside production.

The presence of rosin and its derivatives were affirmed to wild plants of $R$. rosea, $R$. quadrifida and $R$. sachalinensis. In cultivated plants their presence was confirmed only in $R$. kirilowii and $R$. rosea, with higher amounts detected in $R$. rosea. In the in vitro cultures a significant enhancement in the production of rosin and its derivatives was observed when the cultures were fed with the precursor cinnamyl alcohol. In $R$. rosea compact callus aggregate cultures the observed rosin and rosarin content was even higher than in field cultivated plants while the rosavin level was five times lower. The developed hairy root cultures of $R$. kirilowii supplemented with cinnamyl alcohol addition exhibited a multiplied potential for the production of rosin and its derivatives in comparison to field cultivated plants.

The results presented in the review point out that biotechnological methods could be an attractive approach to produce salidroside, rosin and its derivatives at higher or at least comparable levels to wild or cultivated plants.

Open Access This article is distributed under the terms of the Creative Commons Attribution License which permits any use, distribution, and reproduction in any medium, provided the original author(s) and the source are credited.

\section{References}

Abidov M, Crendal F, Grachev S, Seifulla R, Ziegenfuss T (2003) Effect of extracts from Rhodiola rosea and Rhodiola crenulata (Crassulaceae) roots on ATP content in mitochondria of skeletal muscles. Bull Exp Med 136(6): 585-587

Akgul Y, Ferreira D, Abourashed EA, Khan IA (2004) Lotaustralin from Rhodiola rosea roots. Fitoterapia 75: 612-614

Ali Z, Fronczek FR, Khan IA (2008) Phenylalkanoids and monoterpene analogues from the roots of Rhodiola rosea. Planta Med 74:178-181
Altantsetseg K, Przybył J, Węglarz Z, Geszprych A (2007) Content of biologically active compounds in roseroot (Rhodiola spp.) raw material of different derivation. Herba Pol 53(4):20-26

Bozhilova M (2011) Salidroside content in Rhodiola rosea L., dynamics and variability. Bot Serb 35(1):67-70

Brown RP, Gerbarg PL, Ramazanov Z (2002) Rhodiola rosea: a phytomedicinal overview. Herbal Gram 56:40-52

Buchwald W, Mścisz A, Krajewska-Patan A, Furmanowa M, Mielcarek S, Mrozikiewicz PM (2006) Content of biologically active compounds in Rhodiola rosea roots during the vegetation period. Herba Pol 52:39-43

Bykov VA, Zapesochnaya GG, Kurkin VA (1999) Traditional and biotechnological aspects of obtaining medicinal preparations from Rhodiola rosea $\mathrm{L}$. (a review). Pharm Chem J 33(1):29-40

Calcabrini C, De Bellis R, Mancini U, Cucchiarini L, Potenza L, De Sanctis R, Patrone V, Scesa C, Dachà M (2010) Rhodiola rosea ability to enrich cellular antioxidant defences of cultured human keratinocytes. Arch Dermatol Res 302(3):191-200

Chen QG, Zeng YS, Qu ZQ, Tang JY, Qin YJ, Chung P, Wong R, Hägg U (2009a) The effects of Rhodiola rosea extract on 5-HT level, cell proliferation and quantity of neurons at cerebral hippocampus of depressive rats. Phytomedicine 16:830-838

Chen X, Zhang Q, Chen Q, Ding F (2009b) Protective effect of salidroside against $\mathrm{H}_{2} \mathrm{O}_{2}$-induced cell apoptosis in primary culture of rat hippocampal neurons. Mol Cell Biochem 332(1-2):85-93

Chen D, Fan J, Wang P, Zhu L, Jin Y, Peng Y, Du S (2012) Isolation, identification and antioxidative capacity of water-soluble phenylpropanoid compounds from Rhodiola crenulata. Food Chem 134:2126-2133

Cheng YZ, Chen LJ, Lee WJ, Chen MF, Jung Lin H, Cheng JT (2012) Increase of myocardial performance by Rhodiolaethanol extract in diabetic rats. $J$ Ethnopharmacol 144(2):234-239

Choe KI, Kwon JH, Park KH, Oh MH, Kim MH, Kim HH, Cho SH, Chung EK, Ha SY, Lee MW (2012) The antioxidant and anti-inflammatory effects of phenolic compounds isolated from the root of Rhodiola sachalinensis A. BOR. Molecules 17:11484-11494

Darbinyan V, Kteyan A, Panossian A, Gabrielian E, Wikman G, Wagner H (2000) Rhodiola rosea in stress induced fatigue: a double blind cross-over study of a standardized extract SHR-5 with a repeated low-dose regimen on the mental performance of healthy physicians during night duty. Phytomedicine 7(5):365-371

De Bock K, Eijnde BO, Ramaekers M, Hespel P (2004) Acute Rhodiola rosea intake can improve endurance exercise performance. Int J Sport Nutr Exerc Metab 14(3):298-307

Diermen D, Van Marston A, Bravo J, Reist M, Carrupt P, Hostettmann K (2009) Monoamine oxidase inhibition by Rhodiola rosea L. roots. J Ethnopharmacol 122:397-401

Du M, Xie J (1995) Flavonol glycosides from Rhodiola crenulata. Phytochemistry 38(3):809-810

Flora of China (2001) Rhodiola Linnaeus, Sp. Pl 2: 1035.17538:251-268

Furmanowa M, Oledzka H, Michalska M, Sokolnicka I, Radomska D (1995) Rhodiola rosea L. (Roseroot): in vitro 
regeneration and the biological activity of roots. In: Bajaj YPS (ed) Biotechnology in agriculture and forestry, vol 33. Medicinal and Aromatic Plants VIII (pp 412-426). Springer, Berlin

Furmanowa M, Skopinska-Rozewska E, Rogala E, Hartwich M (1998) Rhodiola rosea in vitro culture: phytochemical analysis and antioxidant action. Acta Soc Bot Pol 67:69-73

Furmanowa M, Hartwich M, Alfermann AW, Kozminski W, Olejnik M (1999) Rosavin as a product of glycosylation by Rhodiola rosea (roseroot) cell cultures. Plant Cell Tissue Organ Cult 56:105-110

Galambosi B (2006) Demand and availability of Rhodiola rosea L. in raw material. In Bogers RJ, Craker LE, Lange D (eds) Medicinal and aromatic plants. Netherland, Springer. Ch 16:223-236

Galambosi B, Galambosi ZS, Hethelyi E, Szoke E, Volodin V, Poletaeva I, Lljina I (2010) Importance and quality of roseroot (Rhodiola rosea L.) growing in the European North. Z Arznei-Gewurzpfla 15(4):160-169

GBIF (2010) Biodiversity occurrence data provided by Global Biodiversity Information Facility. http://data.gbif.org

Giri A, Dhingra V, Giri CC, Singh A, Ward OP, Narasu ML (2001) Biotransformations using plant cells, organ cultures and enzyme systems: current trends and future prospects. Biotechnol Adv 19(3):175-199

Grech-Baran M, Syklowska-Baranek K, Giebultowicz J, Wroczynski P, Pietrosiuk A (2013) Tyrosol-glycosyltransferase activity and production of salidroside in natural and transformed root cultures of Rhodiola kirilowii (Regel) Regel et Maximowicz. Acta Biol Cracov Bot 55(2): 126-133

Grech-Baran M, Sykłowska-Baranek K, Krajewska-Patan A, Wyrwał A, Pietrosiuk A (2014) Biotransformation of cinnamyl alcohol to rosavins by non-transformed wild type and hairy root cultures of Rhodiola kirilowii. Biotechnol Lett 36:649-656

Gryszczyńska A, Łowicki Z, Opala B, Krajewska-Patan A, Buchwald W, Czerny B, Mielcarek S, Mrozinkiewicz PM (2012) Comparison of phenylethanoids content in Rhodiola kirilowii and Rhodiola rosea roots using applying new developed UPLC-MS/MS method. Herba Pol 58(4):28-38

Guest HJ, Allen GA (2014) Geographical origins of North American Rhodiola (Crassulaceae) and phylogeography of the western roseroot. J Biogeogr, Rhodiola integrifolia. doi:10.1111/jbi.12267

Gupta V, Lahiri SS, Sultana S, Tulsawani K, Kumar R (2010) Anti-oxidative effect of Rhodiola imbricata root extract in rats during cold hypoxia and restraint $(\mathrm{C}-\mathrm{H}-\mathrm{R})$ exposure and post-stress recovery. Chem Toxicol 48:1019-1025

György Z (2006) Glucoside production by in vitro Rhodiola rosea cultures. Dissertation, Acta Universitatis Ouluensis C Technica 244. Oulu

Gyorgy Z, Jaakola L, Neubauer P, Hohtola A (2009) Isolation and genotype-dependent, organ-specific expression analysis of a Rhodiola rosea cDNA encoding tyrosine decarboxylase. J Plant Physiol 166:1581-1586

György Z, Tolonen A, Pakonen M, Neubauer P, Hohtola A (2004) Enhancing the production of cinnamyl glycosides in compact callus aggregate cultures of Rhodiola rosea by biotransformation of cinnamyl alcohol. Plant Sci 166(1):229-236
György Z, Tolonen A, Neubauer P, Hohtola A (2005) Enhanced biotransformation capacity of Rhodiola rosea callus cultures for glycoside production. Plant Cell Tissue Organ Cult 83(2):129-135

Hu X, Lin S, Yu D, Qiu S, Zhang X, Mei R (2010a) A preliminary study: the anti-proliferation effect of salidroside on different human cancer cell lines. Cell Biol Toxicol 26:499-507

Hu X, Zhang X, Qiu S, Yu D, Lin S (2010b) Salidroside induces cell-cycle arrest and apoptosis in human breast cancer cells. Biochem Biophys Res Commun 398(1):62-67

Hung SK, Perry R, Ernst E (2011) The effectiveness and efficacy of Rhodiola rosea L.: a systematic review of randomized clinical trials. Phytomedicine 18(4):235-244

Kang S, Zhang J, Lu Y, Lu D (1992) Chemical constituents of Rhodiola kirilowii (Reg.) Reg. China J Chin Mater Med 17(2):1001-1027

Kolewe ME, Gaurav V, Roberts SC (2008) Pharmaceutically active natural product synthesis and supply via plant cell culture technology. Mol Pharm 5(2):243-256

Kołodziej B, Sugier D (2012) Selected elements of biology and morphology of Roseroot in South-Eastern Poland. Acta Sci Pol Hortorum 11(5):127-142

Komarov WL, Juzepczyk SV (ed) (1939) Flora SSSR. MoscowLeningrad IX, pp 24-53

Krajewska-Patan A, Furmanowa M, Mścisz A, Derger M, Łowicka A, Górska-Paukszta M, Mielcarek S, Mrozikiewicz PM (2006) Tissue cultures of Rhodiola Kirilowii (Regel.) Maxim: contents of biologically active components at different stages of growth. Herba Pol 52:98-106

Krajewska-Patan A, Dreger M, Łowicka A, Górska-Pauszkta M, Mścirz A, Mielcarek S, Baraniak M, Buchwald W, Furmanowa M, Mrozikiewicz PM (2007a) Chemical investigations of biotransformed Rhodiola rosea callus tissue. Herba Pol 53(4):77-87

Krajewska-Patan A, Furmanowa M, Dreger M, Górska-Paukszta M, Łowicka A, Mścisz A, Mielcarek S, Baraniak M, Buchwald W, Mrozikiewicz PM (2007b) Enhancing the biosynthesis of salidroside by biotransformation of p-tyrosol in callus culture of Rhodiola rosea L. Herba Pol 53(1):55-64

Krajewska-Patan A, Derger M, Łowicka A, Górska-Paukszta M, Furmanowa M, Mścisz A, Mielcarek S, Baraniak M, Mrozikiewicz PM (2008a) Rhodiola rosea and Rhodiola kirilowii callus cultures in biotransformation process. II national conference "genetics and genomics in crop improvement-from a model plant to a new cultivar". Poznań, 24-26 November, Abstracts: 12

Krajewska-Patan A, Furmanowa M, Derger M, Mścisz A, Mielcarek S, Kania M, Buchwald W, Baraniak M, Pietrosiuk A, Zych M, Karasiewicz M, Bogacz A, Kujawski R, Mrozikiewicz PM (2008b) Rhodiola kirilowii: the present status and perspectives of medicinal use. Part I. In vivo and in vitro cultivation as well as phytochemical investigations of extracts of roots and callus tissues. Herba Pol 54:47-48

Krajewska-Patan A, Dreger M, Buchwald W, Górska -Paukszta M, Mielcarek S, Baraniak M, Mścisz A, Furmanowa M, Mrozikiewicz PM (2009) Callus tissues of Rhodiola kirilowii (Regel) Maxim.- dynamics of growth and active compounds production. Herba Pol 55(3):222-230 
Krajewska-Patan A, Gryszczyńska A, Mielcarek S, Furmanowa M, Buchwald W, Mikołajczak PM, Czerny B, Mrozikiewicz PM (2013) Possible Rhodiola kirilowii use in modern phytotherapy. Postępy Fitoterapii 1:22-27

Krasnov EA, Kuvaiev VB, Chorużaya TG (1978) Chemotaxonomic investigations of Rhodiola spp. Rast Res 14(2):153-160

Kucharski W, Mordalski R, Buchwald W, Mielcarek S (2011) Roseroot: the comparison of tillage in conventional and ecological system. J Res Appl Agric Eng 56(3):232-235

Kurkin VA, Zapesochnaya GG (1986) Chemical composition and pharmacological properties of Rhodiola rosea. Chem Pharm J (Moscow) 20(10):1231-1244

Kurkin VA, Zapesochnaya GG, Shchavlinskii AN, Nukhimovskii EL, Vandyshev VV (1985) Metod opredeleniya podlinnosti i kachestva kornevishch rodioly rozovoj (Methods of analysis of identity and quality of Rhodiola rosea roots). Khim Farm Zh 19:185-190

Kurkin VA, Zapesochnaya GG, Gorbunov YN, Nukhimovskii EL, Sreter AI, Shchavlinskii AN (1986) Chemical investigations on some species of Rhodiola L. and Sedum L. genera and problemes of their chemotaxonomy. Rast Res 22(3):310-319

Lee MW, Lee YA, Park HM, Toh SH, Lee EJ, Jang HD, Kim YH (2000) Antioxidative phenolic compounds from the roots of Rhodiola sachalinensis A. Bor. Arch Pharm Res 23(5):455-458

Li HB, Chen F (2001) Preparative isolation and purification of salidroside from the Chinese medicinal plant Rhodiola sachalinensis by high-speed counter-current chromatography. J Chromatogr A 932:91-95

Liu Z, Liu Y, Liu C, Song Z, Li Q, Zha Q, Lu C, Wang C, Ning Z, Zhang Y, Tian C, Lu A (2013) The chemotaxonomic classification of Rhodiola plants and its correlation with morphological characteristics and genetic taxonomy. Chem Cent J 7:118

Ma LQ, Liu BY, Gao DY, Pang XB, Lü SY, Yu HS, Wang H, Yan F, Li ZQ, Li YF, Ye HC (2007) Molecular cloning and overexpression of a novel UDP-glucosyltransferase elevating salidroside levels in Rhodiola sachalinensis. Plant Cell Rep 26(7):989-999

Ma LQ, Gao DY, Wang YN, Wang HH, Zhang JX, Pang XB, Hu TS, Lu SY, Li GF, Ye HC, Li YF, Wang H (2008) Effects of overexpression of endogenous phenylalanine ammonialyase (PALrs1) on accumulation of salidroside in Rhodiola sachalinensis. Plant Biol 10:323-333

Ma C, Hu L, Fu Q, Gu X, Tao G, Wang H (2013) Separation of four flavonoids from Rhodiola rosea by on-line combination of sample preparation and counter-current chromatography. J Chromatogr A 1306:12-29

Mao GX, Wang Y, Qiu Q, Deng HB, Yuan LG, Li RG, Song DQ, Li YY, Li DD, Wang Z (2010) Salidroside protects human fibroblast cells from premature senescence induced by $\mathrm{H}_{2} \mathrm{O}_{2}$ partly through modulating oxidative status. Mech Ageing Dev 131(11-12):723-731

Meng QY, Jiang ML, Zhong WT, Cheng GH, Liu SHY, Ma QL (1994) Controlling the root-rot disease of Rhodiola sachalinensis A. Bor with pesticides (Chinese). J Shenyang Agric Univ 25(3):264-267

Nakamura S, Li X, Matsuda H, Yoshikawa M (2007) Bioactive constituents from Chinese natural medicines. XXVIII.
Chemical structures of acyclic alcohol glycosides from the roots of Rhodiola crenulata. Chem Pharm Bull 55(10):1505-1511

Nakamura S, Li X, Matsuda H, Yoshikawa M (2008) Bioactive constituents from Chinese natural medicines. XXVIII. Chemical structures of acyclic alcohol glycosides from the roots of Rhodiola crenulata. Chem Pharm Bull 56(4):536-540

Nan JX, Jiang YZ, Park EJ, Ko GK, Youn-Chul S, Sohn DH (2003) Protective effect of Rhodiola sachalinensis extract on carbon tetrachloride-induced liver injury in rats. J Ethnopharmacol 84:143-148

Nitsch J, Nitsch C (1969) Haploid plants from pollen grains. Science 169:85-87

Oksman-Caldentey KM, Inze D (2004) Plant cell factories in the post-genomic era: new ways to produce designer secondary metabolites. Trends Plant Sci 9(9):433-440

Olsson EM, Schéele B, Panossian A (2009) A randomized, double-blind, placebo-controlled, parallel-group study of the standardized extract SHR-5 of the roots of Rhodiola rosea in the treatment of subjects with stress-related fatigue. Planta Med 75(2):2105-2112

Panossian A, Wikman G, Sarris J (2010) Rosenroot (Rhodiola rosea): traditional use, chemical composition, pharmacology and clinical efficacy. Phytomedicine 17(7):481-493

Patov SA, Punegov VV, Kuchin AV (2006) Synthesis of the Rhodiola rosea glycoside rosavin. Chem Nat Compd 42:397-399

Peng JN, Ma CY, Ge YC (1995) Studies on the chemical constituents of Rhodiola crenulata. Chin Tradit Herb Drugs 26(4):177-179

Peschel W, Prieto JM, Karkour C, Williamson EM (2013) Effect of provenance, plant part and processing on extract profiles from cultivated European Rhodiola rosea L. for medicinal use. Phytochemistry 86:92-102

Plant List. http://www.theplantlist.org

Platikanov S, Evstatieva L (2008) Introduction of wild golden root (Rhodiola rosea $\mathrm{L}$ ) as a potential economic crop in Bulgaria. Econ Bot 64(4):621-627

Przybył J, Węglarz Z, Geszprych A (2008) Quality of roseroot (Rhodiola rosea L.) cultivated in Poland. Acta Hort 765:143-150

Ramachandra Rao S, Ravishankar GA (2002) Plant cell cultures: chemical factories of secondary metabolites. Biotechnol Adv 20(2):101-153

Revina TA, Krasnov EA, Sviridova TP, Stepanyuk GY, Surov YP (1976) Biological characteristics and chemical composition of Rhodiola rosea grown in Tomsk. Rast Res 12(3):355-360

Russian Pharmacopeia (1989) Rhizomata et Radices Rhodiolae roseae. 11th eds, vol. 2 Meditsina, Moskva

Saratikov AS, Krasnov EA (1987) Rhodiola rosea is a valuable medicinal plant (Golden Root). Tomsk, Russia: Tomsk State University

Saratikov AS, Krasnov EA, Khnikina LA, Duvidson LM (1967) Isolation and chemical analysis of individual biologically active constituents of Rhodiola rosea. Proceedings of the Siberian Academy of Sciences. Biology 1:54-60

Saunders D, Poppleton DI, Struchkov A, Ireland RJ (2013) Analysis of five bioactive compounds from naturally occurring Rhodiola rosea in Eastern Canada. Can J Plant Sci. doi:10.4141/CJPS2013-177 
Schriner SE, Avanesian A, Liu Y, Luesch H, Jafari M (2009) Protection of human cultured cells against oxidative stress by Rhodiola rosea without activation of antioxidant defenses. Free Rad Biol Med 47(5):577-584

Seo WG, Pae HO, Oh GS, Kim NY, Kwon TO, Kwon TO, Shin MK, Chai KY, Chung HT (2001) The aqueous extract of Rhodiola sachalinensis root enhances the expression of inducible nitric oxide synthase gene in RAW264.7 macrophages. J Ethnopharmacol 76(1):119-123

Sheng CZ, Hu TQ, Bi H, Yuan YJ, Jiang Y (2005) Effects of plant growth substances on induction and culture of callus from Rhodiola quadrifida. Zhongguo Zhong Yao Za Zhi 30(16): 1237-1240

Shi T, Chen H, Jing L, Liu X, Sun X, Jiang R (2011) Development of a kilogram-scale synthesis of salidroside and its analogs. Synth Commun 41:2594-2600

Shi L, Wang C, Zhou X, Zhang Y, Liu Y, Ma C (2013) Production of salidroside and tyrosol in cell suspension cultures of Rhodiola crenulata. Plant Cell Tiss Organ Cult 114:295-303

Shilpa K, Varun K, Lakshimi BS (2010) An alternate method of natural drug production: eliciting secondary metabolite production using plant cell culture. J Plant Sci 5(3): 222-247

Siwicki AK, Skopińska-Różewska E, Wasiutyński A, Wójcik R, Zdanowski R, Sommer E (2012) The effect of Rhodiola kirilowii extracts on pigs blood leukocytes metabolic (RBA) and proliferative (LPS) activity, and on the bacterial infection and blood leukocytes number in mice. Cent Eur J Immunol 37(2):145-150

Skopińska-Różewska E, Hartwich M, Andrzej K, Siwicki AK, Wasiutyński A, Sommer E, Mazurkiewicz M, Bany J, Skurzak H (2008a) The influence of Rhodiola rosea extracts and rosavin on cutaneous angiogenesis induced in mice after grafting of syngeneic tumor cells. Cent Eur J Immunol 33(3):102-107

Skopińska-Różewska E, Malinowski M, Wasiutyński A, Sommer E, Furmanowa M, Mazurkiewicz M, Siwicki AK (2008b) The influence of Rhodiola quadrifida 50\% hydroalcoholic extract and salidroside on tumor-induced angiogenesis in mice. Pol J Vet Sci 11(2):97-104

Skopińska-Różewska E, Wasiutyński A, Sommer E, Sebastian Mielcarek S, Mścisz A, Krajewska-Patan A, Mazurkiewicz M, Pastewka K (2008c) The influence of Rhodiola rosea, Rhodiola kirilowii and Rhodiola quadrifida extracts on cutaneous angiogenesis induced in mice after grafting of human kidney cancer tissue. Cent Eur J Immunol 33(4): 185-189

Sokolov SJ, Ivashkin VM, Zapesochnaya GG, Kurkin VA, Shchavlinsky AN (1985) Isledovan'ye neyrotropnoy aktivnostinovykh veshchestv vydelenykh iz rodioly rozovoy (Studies on neurotropic activity of new compounds isolated from Rhodiola rosea) Khim. Farm Zh 19:1367-1371 [In Russian]

Sokolov SJ, Boiko VP, Kurkin VA, Zapesochnaya GG, Rvantsova NV, Grinenko NA (1990) Sravnitel'noe isledovan'e stimuliruyushchikh svoistv nekotorykh fenilpropanoidov (Comparative examination of stimulant properties of some phenylpropanoids) Khim. Farm $\mathrm{Zh}$ 1:66-68 [In Russian]
Spasov AA, Wikman GK, Mandrikov VB, Mironova IA, Neumoin VV (2000) A double-blind, placebo-controlled pilot study of the stimulating and adaptogenic effect of Rhodiola rosea SHR-5 extract on the fatigue of students caused by stress during an examination period with a repeated lowdose regimen. Phytomedicine 7(2):85-89

Su XF, Zhang H, Shao JX, Wu HY (2007) Theoretical study on the structure and properties of crenulatin molecule in herb Rhodiola crenulata. J Mol Struct 847(1-3):59-67

Sun C, Wang Z, Zheng Q, Zhang H (2012) Salidroside inhibits migration and invasion of human fibrosarcoma HT1080 cells. Phytomedicine 19(3-4):355-363

Tao GR, Zhao YP, Qi JH, Xu K, Yang L (2010) Salidroside contents of Rhodiola plants growing in different regions. Acta Bot Boreal Occident Sin 30(9):567

Tasheva K, Kosturkova G (2010) Bulgarian golden root in vitro cultures for micropropagation and reintroduction. Cent Eur J Biol 5(6):853-863

Tolonen A, Pakonen M, Hohtola A, Jalonen J (2003) Phenylpropanoid glycosides form Rhodiola rosea. Chem Pharm Bull 51(4):467-470

Tutin TG (1964) Flora Europaea. Cambridge University Press, Cambridge

Vijaya SN, Udayasri PV, Aswani KY, Ravi BB, Phani KY, Vijay VM (2010) Advancements in the production of secondary metabolites. J Nat Prod 3:112-123

Wagner H, Nörr H, Winterhof H (1994) Plant adaptogens. Phytomedicine 1(1):63-76

Wang S, Wang FP (1992) Studies on the chemical components of Rhodiola crenulata. Yao Xue Xue Bao 27(2):117-120

Wang J, Rong X, Li W, Yang Y, Yamahara J, Li Y (2012) Rhodiola crenulata root ameliorates derangements of glucose and lipid metabolism in a rat mode lo the metabolic syndrome and type2 diabetes. J Ethnopharmacol 142: 782-788

Węglarz Z, Przybył J, Geszprych A (2008) Roseroot (Rhodiola rosea $\mathrm{L}$.): effect of internal and external factors on accumulation of biologically active compounds. In: Ramawat KG, Merillon JM (eds) Bioactive molecules and medicinal plants. Berlin 16:297-315

Wiedenfeld H, Dumaa M, Malinowski M, Furmanowa M, Narantuya S (2007a) Phytochemical and analytical studies of extracts from Rhodiola rosea and Rhodiola quadrifida. Pharmazie 62(4):308-311

Wiedenfeld H, Zych M, Buchwald W, Furmanowa M (2007b) New compounds from Rhodiola kirilowii. Sci Pharm 75:29-34

Wójcik R, Siwicki AK, Skopińska-Różewska E, Wasiutyński A, Sommer E, Furmanowa M (2009) The effect of Chinese medicinal herb Rhodiola kirilowii extracts on cellular immunity in mice and rats. Pol J Vet Sci 12(3):399-405

Wong YC, Zhao M, Zong YY, Chan CY, Che CT (2008) Chemical constituents and anti-tuberculosis activity of root of Rhodiola kirilowii. China J Chin Mater Med 33(13): 1561-1565

Wu S, Zu Y, Wu M (2003) High yield production of salidroside in the suspension culture of Rhodiola sachalinensis. J Biotechnol 106(1):33-43

Wu T, Zhou H, Jin Z, Bi S, Yang X, Yi D, Liu W (2009) Cardioprotection of salidroside from ischemia/reperfusion 
injury by increasing $\mathrm{N}$-acetylglucosamine linkage to cellular proteins. Eur J Pharmacol 613(1-3):93-99

Xu JF, Su ZG (1997) Regulation of metabolism for improved salidroside production in cell suspension culture of Rhodiola sachalinensis A. Bor: the effect of precursors. Nat Prod Res Dev 10:8-14 [In Chinese]

Xu J, Xie J, Han A, Feng P, Su Z (1998a) Kinetic and technical studies on large-scale culture of Rhodiola sachalinensis compact callus aggregates with air-lift reactors. J Chem Technol Biotechnol 72:227-234

Xu JF, Liu CB, Han AM, Feng PS, Su ZG (1998b) Strategies for the improvement of salidroside production in cell suspension cultures of Rhodiola sachalinensis. Plant Cell Rep 17(4):288-293

Xu JF, Su ZG, Feng PS (1998c) Activity of tyrosol glucosyltransferase and improved salidroside production through biotransformation of tyrosol in Rhodiola sachalinensis cell cultures. J Biotechnol 61(1):69-73

Xu JF, Ying PQ, Han AM, Su ZG (1999) Enhanced salidroside production in liquid-cultivated compact callus aggregates of Rhodiola sachalinensis: manipulation of plant growth regulators and sucrose. Plant Cell Tissue Organ Cult 55: $53-58$

Yan X, Wu S, Wang Y, Shang X, Dai S (2004) Soil nutrient factors related to salidroside production of Rhodiola sachalinensis distributed in Chang Bai Mountain. Environ Exp Bot 52:267-276

Yao K, Luca VD, Brisson N (1995) Creation of a metabolic sink for tryptophan alters the phenylpropanoid pathway and the susceptibility of potato to Phytophthora infestans. Plant Cell 7:1787-1799

Yoshikawa M, Shimada H, Shimoda H, Murakami N, Yamahara J, Matsuda H (1996) Bioactive constituents of Chinese natural medicines. II. Rhodiolae radix. (1). Chemical structures and antiallergic activity of rhodiocyanosides A and $\mathrm{B}$ from the underground part of Rhodiola quadrifida (Pall.) Fisch. et Mey. (Crassulaceae). Chem Pharm Bull 44(11):2086-2091

Yousef GG, Grace MH, Cheng DM, Belolipov IV, Raskin I, Lila MA (2006) Comparative phytochemical characterization of three Rhodiola species. Phytochemistry 67(21):2380-2391
Yu S, Liu M, Gu X, Ding F (2008) Neuroprotective effects of salidroside in the PC12 cell model exposed to hypoglycemia and serum limitation. Cell Mol Neurobiol 28(8): 1067-1078

Yu S, Shen Y, Liu J, Ding F (2010) Involvement of ERK1/2 pathway in neuroprotection by salidroside against hydrogen peroxide-induced apoptotic cell death. J Mol Neurosci 40(3):321-331

Yu HS, Ma LQ, Zhang JX, Shi GL, Hu YH, Wang YN (2011) Characterization of glucosyltransferases responsible for salidroside biosynthesis in Rhodiola sachalinensis. Phytochemistry 72:862-870

Zapesochnaya GG, Kurkin VA, Boyko VP, Kolhir VK (1995) Fenilpropanoidy - perspektivichnye biologicheski aktivnye veshchestva lekarstvennykh rasteniy (Phenylpropanoids as prospective bioactive substances from medicinal plants) Khim. Farm Zh 29(4):47-50

Zhang L, Yu H, Sun Y, Lin X, Chen B, Tan C, Cao G, Wang Z (2007a) Protective effects of salidroside on hydrogen peroxide-induced apoptosis in SH-SY5Y human neuroblastoma cells. Eur J Pharmacol 564(1-3):18-25

Zhang S, Bi H, Liu C (2007b) Extraction of bio-active components from Rhodiola sachalinensis under ultrahigh hydrostatic pressure. Sep Purif Technol 57(2):277-282

Zhang JX, Ma LQ, Yu HS, Zhang H, Wang HT, Qin YF, Shi GL, Wang YN (2011) A tyrosine decarboxylase catalyzes the initial reaction of the salidroside biosynthesis pathway in Rhodiola sachalinensis. Plant Cell Rep 30:1443-1453

Zhou X, Wu Y, Wang X, Liu B, Xu H (2007) Salidroside production by hairy roots of Rhodiola sachalinensis obtained after transformation with Agrobacterium rhizogenes. Biol Pharm Bull 30(3):439-442

Zhou J, Xie G, Yan X (2011) Encyclopedia of traditional Chinese medicines: molecular structures, pharmacological activities, natural sources and applications: vol 4, Isolated compounds, pp 416 Springer, Heidelberg

Zuo G, Li Z, Chen L, Xu X (2007) Activity of compounds from Chinese herbal medicine Rhodiola kirilowii (Regel) Maxim against HCV S3 serine protease. Antiviral Res 76(1):86-92 